\title{
Impact of the surgical implantation of acoustic transmitters on the condition and health of pikeperch (Sander lucioperca (L.))
}

\author{
Zdzisław Zakęś, Maciej Rożyński, Andrzej Kapusta, Elżbieta Ziomek, \\ Krystyna Demska-Zakęś
}

Received - 01 March 2018/Accepted - 28 August 2018. Published online: 30 September 2018; OInland Fisheries Institute in Olsztyn, Poland Citation: Zakęś Z., Rożyński M., Kapusta A., Ziomek E., Demska-Zakęś K. 2018 - Impact of the surgical implantation of acoustic transmitters on the condition and health of pikeperch (Sander lucioperca (L.)) - Fish. Aquat. Life 26: 185-192.

\begin{abstract}
The aim of the study was to determine the impact the surgical implantation of acoustic transmitters (AT; implantation incisions were sutured with tissue adhesive) had on the condition and health of pikeperch, Sander lucioperca (L.), (initial body weight of approximately $600 \mathrm{~g}$ ). After tagging, the fish were held for 42 days in recirculating aquaculture systems. During this period, no negative effects were observed stemming from the implantation of AT on fish growth, condition, survival, or foraging effectiveness. The procedure also did not have a negative impact on hematological indicators. Among the 13 biochemical blood plasma indicators analyzed, only glucose level in the fish tagged with AT was significantly lower than that in the control group $(\mathrm{P} \leq 0.05)$. The rate of wound healing and the condition of the implantation incisions raised no concerns. Three weeks following the AT implantation procedure the incisions were closed and no infection was noted. Short-term AT retention (42 days) was $83.3 \%$, and the fish shed the tags in the first two weeks following implantation.
\end{abstract}

Z. Zakęś [ [”], M. Rożyński

Department of Aquaculture, Inland Fisheries Institute in Olsztyn Oczapowskiego 10, 10-719 Olsztyn, Poland

e-mail: zakes@infish.com.pl; tel. +48 895240171; fax +48

895240505

\section{A. Kapusta}

Department of Ichthyology, Hydrobiology, and Aquatic Ecology, Inland Fisheries Institute in Olsztyn, Poland

\section{E. Ziomek, K. Demska-Zakęś}

Department of Ichthyology, Faculty of Environmental Sciences, University of Warmia and Mazury in Olsztyn, Poland
Keywords: telemetry transmitters, pikeperch, recirculating aquaculture systems, hematological indicators, biochemical blood plasma indicators

Biotelemetry is one of the most effective methods for researching the biology of species and for the effective management of populations. In ichthyological research it serves to gather information on topics such as fish migrations, habitats, behavior, survival, and the effectiveness of stocking in its broadest sense (Hockersmith and Beeman 2012, Thorstad et al. 2013). Initially, because of the size of the transmitters, this technique was used in studies of larger animals, and even then it was applied sporadically. Over the past two decades increasingly large numbers of studies have employed biotelemetry, and substantial technological progress has been made. Currently, for example, the miniaturization of telemetry transmitters means that they can be used even in specimens weighing just a few grams. To date, studies have focused on over 500 fish species (Hussey et al. 2015), including pikeperch, Sander lucioperca (L.), and this technique has been used in research on homing behavior (Keskinen 2005), migration (Jepsen et al. 1999, Jepsen 2003, Poulet et al. 2005), and the daily activity of this species (Horký et al. 2008). 
Transmitters can be placed in the body cavity, in the stomach, or attached externally (Thorstad et al. 2013). Telemetry transmitter implantation is a surgical procedure that can impact fish condition, physiology, and behavior (Cooke et al. 2011). Usually, the impact this procedure has on the growth rate, condition, motor activity, and survival of the tagged fish is analyzed. Physiological tests are rare, and most of them have been conducted in recent years (Cooke et al. 2011). They are based primarily on blood tests (Caputo et al. 2009, Rożyński et al. 2017a). Hematological and biochemical peripheral blood parameters are used to assess fish health. For example, biochemical parameters (cortisol, glucose, total protein, magnesium, etc.) are important tools for assesing the impacts of stress, feeding, and also the water-mineral balance in fish (Brinn et al. 2012). Hematological indexes reflect the physiological response of fish to manipulations and to changes in the environment (Val et al. 1992).

The aim of the study was to determine the impact the surgical procedure of implanting the telemetry transmitters (acoustic-AT) had on the pikeperch growth, condition, survival, and hematological and biochemical parameters. The healing of the AT implantation incisions was also analyzed.

The experimental material was obtained from out-of-season spawning, and larval and juvenile pikeperch stages were reared in recirculating aquaculture systems (RAS) (FAO 2012). These fish had a mean body weight (BW) of $610.7 \pm 23.3 \mathrm{~g}$ (mean \pm SD) and a mean body length (SL) of $36.2 \pm$ $0.4 \mathrm{~cm}$ (mean $\pm \mathrm{SD}$ ). First, 36 specimens were tagged with passive integrated transponders (PIT; Fish Eagle, Lechlade, Great Britain) (material bio-glass; length $12.0 \pm 0.4 \mathrm{~mm}$; diameter $-2.12 \pm$ $0.07 \mathrm{~mm}$; weight - $93 \mathrm{mg}$ ). The fish were tagged with PIT in the cheek (Zakęś and Hopko 2013). After the fish were tagged with PIT and had recovered from general anesthesia, they were placed into RAS. Twenty-four hours later, acoustic transmitters (AT) (Vemco, Bedford, Canada) were surgically implanted into the pikeperch. Dummy transmitters were used that are identical to model V9AP, which are cylindrical with a declared weight (in air) of $6.6 \mathrm{~g}$, a length of
$48 \mathrm{~mm}$, and a diameter of $9 \mathrm{~mm}$. The weight of the transmitters (in air) ranged from 6.34 to $6.48 \mathrm{~g}$ (mean $6.41 \mathrm{~g})$. The relative weight of the ATs and PITs [100 $\times$ (weight of the transmitters and PIT $(\mathrm{g}) \times \mathrm{BW}(\mathrm{g})]$ (measurements in air) was a mean of $<1.07 \% \mathrm{BW}$ (range of 0.86-1.24\% BW). The pikeperch were anesthetized with an aqueous solution of etomidate (Propiscin, IRS Olsztyn, Poland) at a dose of $2 \mathrm{ml} \mathrm{l}^{-1}$ before the implantation procedure. After 3-4 min, general anesthesia was induced in the fish as they exhibited a loss of balance and no reaction to external stimuli (Kristan et al. 2014). The transmitters were implanted in the body cavity through a 20-30 mm incision made with a Swann-Morton scalpel (Sheffield, Great Britain) approximately $50 \mathrm{~mm}$ posterior to the pectoral fin and $5 \mathrm{~mm}$ from the linea alba (Wagner et al. 2011, Rożyński et al. 2017a). The incisions were sutured with Surgibond (SMI AG, St. Vith, Belgium). After the procedure, the incisions were disinfected with Betadine (Lavipharm, Peania, Greece). The acoustic transmitter implantation procedure took an average of $83 \mathrm{~s}$ (range 56-130 s). The fish were then allowed to recover from general anesthesia in a container filled with well-oxygenated water (volume 40 1). In total, 18 specimens were tagged with AT and stocked into three rearing tanks (6 fish tank ${ }^{-1}$; group AT; $n=3)$. Fish from the control group (18 specimens tagged with PIT only) were subjected to the same procedure as the experimental fish (with the exception of the incision and AT implantation) and were stocked into three tanks (6 fish $\operatorname{tank}^{-1}$; group C; $n=3)$. The fish were reared in rotating tanks with volumes of $0.25 \mathrm{~m}^{3}$ that were part of a RAS. The mean biomass per tank was $16.04 \mathrm{~kg} \mathrm{~m}^{-3}$. The fish were reared for six weeks.

The water temperature $\left( \pm 0.1^{\circ} \mathrm{C}\right)$ and oxygen concentration $\left( \pm 0.01 \mathrm{mg} \mathrm{O}_{2} \mathrm{l}^{-1}\right)$ at the rearing tank inflows and outflows were measured daily. The amounts of total ammonia nitrogen $\left(\mathrm{TAN}=\mathrm{NH}_{4}{ }^{+}-\mathrm{N}\right.$ $+\mathrm{NH}_{3}-\mathrm{N} ; \pm 0.01 \mathrm{mg}$ TAN l$\left.{ }^{-1}\right)$, nitrites $\left(\mathrm{NO}_{2}-\mathrm{N} ; \pm\right.$ $\left.0.01 \mathrm{mg} \mathrm{NO}_{2}-\mathrm{N} \mathrm{l}^{-1}\right)$, and $\mathrm{pH}( \pm 0.01)$ were measured at the rearing tank outflows weekly. Water temperature was maintained at $22.0 \pm 0.2^{\circ} \mathrm{C}$. The oxygen concentration measured at the rearing tank outflows did not fall below $6.82 \mathrm{mg} \mathrm{O}_{2} \mathrm{l}^{-1}$ (saturation > 77.4\%). 
Concentrations of ammonia and nitrites at the rearing tank outflows did not exceed $0.24 \mathrm{mg} \mathrm{TAN}^{-1}$ and $0.017 \mathrm{mg} \mathrm{NO}_{2}-\mathrm{N} \mathrm{l}^{-1}$. Water $\mathrm{pH}$ at the rearing tank outflows ranged from 7.95 to 8.14. The fish were fed Aller Bronze $4.5 \mathrm{~mm}$ (Aller Aqua, Christiansfeld, Denmark), which had a proximate composition of protein $-45.0 \%$, fat $-15.0 \%$, carbohydrates $-23.8 \%$, ash $-6.9 \%$, and digestible energy $-17.6 \mathrm{MJ} \mathrm{kg}^{-1}$. The feed was delivered with an automatic band feeder for $18 \mathrm{~h} \mathrm{~d}^{-1}$ (09:00-03:00) (FIAP, Fishtechnik GmbH, Ursensollen, Germany). The daily feed ration was determined weekly at $0.7 \%$ of the fish biomass.

The fish were weighed and measured individually immediately before AT implantation on day 0 (d0; BW $\pm 0.1 \mathrm{~g} ; \mathrm{SL} \pm 0.1 \mathrm{~cm})$. Subsequent measurements of specimens were taken every seven days (d7, d14, d21, d28, d35, d42). During these measurements, each specimen was identified with a PIT reader (Fish Eagle, Lechlade, Great Britain), tissue adhesive retention was assessed (Deters et al. 2010, Rożyński et al. 2017a), and the state of the abdominal incisions was examined macroscopically (Miller et al. 2014, Rożyński et al. 2017a). The amounts of feed consumed, the presence of shed PITs and ATs, and the behavior and mortality of the fish were monitored daily. These data served to calculate the following: daily growth rate $-\mathrm{DGR}\left(\mathrm{g} \mathrm{d}^{-1}\right)=\left(\mathrm{BW}_{2}-\mathrm{BW}_{1}\right) \times$ $\mathrm{t}^{-1}$, specific growth rate - SGR $\left(\% \mathrm{~d}^{-1}\right)=100 \times(\mathrm{ln}$ $\left.\mathrm{BW}_{2}-\ln \mathrm{BW}_{1}\right) \times \mathrm{t}^{-1}$; Fulton's condition coefficient $\mathrm{F}=100 \times \mathrm{BW} \times \mathrm{SL}^{-3}$, feed conversion ratio $-\mathrm{FCR}=$ $\mathrm{TFS} \times(\mathrm{FB}-\mathrm{IB})^{-1}, \mathrm{AT}$ retention $-\mathrm{R}(\%)=100 \times\left(\mathrm{N}_{2} \times\right.$ $\mathrm{N}_{1}^{-1}$ ), where $\mathrm{BW}_{1}$ is initial fish body weight $(\mathrm{g}), \mathrm{BW}_{2}$ is final fish body weight $(\mathrm{g}), \mathrm{t}$ is rearing time (days), $\mathrm{SL}$ is fish body length (cm), FB is final stock biomass (g), IB is initial stock biomass (g), TFS is total feed supply (g), $N_{1}$ is the total number of fish on the final day of the experiment (specimens), and $\mathrm{N}_{2}$ is the number of fish with AT on the final day of the experiment (specimens).

On the final day of the experiment (d42), approximately $1 \mathrm{ml}$ of blood was drawn directly from the caudal vein of each specimen with a heparinized syringe (Sarstedt AG \& Co., Nümbrecht, Germany). The samples were used to determine the following hematological indexes: white blood cell count
(WBC), red blood cell count (RBC), hemoglobin (HGB), hematocrit (HCT), and platelets (PLT). The samples were also used to determine the following red blood cell indexes: mean corpuscular volume (MCV), mean corpuscular hemoglobin (MCH), and mean corpuscular hemoglobin concentration (MCHC). Portions of the blood samples were centrifuged at $6500 \mathrm{rpm}$ for $2 \mathrm{~min}$ at a temperature of $20^{\circ} \mathrm{C}$ (Fresco 17, Thermo Scientific, Waltham, USA). The material obtained was used to determine the following biochemical indexes: creatinine (CREA), total protein (TP), albumin (ALB), globulin (GLB), glucose (GLU), lactates (LACT), total bilirubin (BIL-T), alanine aminotransferase (ALT), aspartate aminotransferase (AST), alkaline phosphatase (ALP), calcium (Ca), chlorine (Cl), magnesium (Mg), and ammonia $\left(\mathrm{NH}_{3}\right)$. Hematological measurements were performed with a BC-2800 VET semi-automatic hematology analyzer (Mindray, Shenzhen, China), while biochemical measurements were performed with a BS-120 automatic chemistry analyzer (Mindray, Shenzhen, China).

Statistical analysis was performed with Statistica 12 (StatSoft Inc., USA). The normality of distribution was tested with the Shapiro-Wilk test, while the homogeneity of variance was tested with Levene's test. The statistical significance of growth data and incision assessments was verified with single factor analysis of variance (ANOVA) with repeated measurements. If the test indicated statistical significance, further analysis was performed with Tukey's test, and differences were significant at $\mathrm{P} \leq 0.05$. Statistical significance for the hematological and biochemical indexes was tested with the Mann-Whitney $\mathrm{U}$ test, and differences were significant at $\mathrm{P} \leq 0.05$.

No significant differences were confirmed with regard to growth rates or condition between pikeperch tagged with AT (group AT) and the control group (group C) (Table 1; P > 0.05). However, highly differentiated values of the parameters tested were noted within both the AT and C groups. A similar phenomenon was observed when tagging juvenile pikeperch (BW approximately $87 \mathrm{~g}$; SL approximately $20 \mathrm{~cm}$ ) with radio transmitters (RT) (Rożyński et al. 2017a). The phenomenon known as 
Table 1

Growth, condition, feed conversion ratio, mortality, and acoustic transmitter retention in pikeperch (S. lucioperca) (specimens tagged with acoustic transmitters group AT, fish from the control group-group C) on subsequent days of the experiment (d0-day fish were tagged; d7, d14, d21, d28, d35, d42, respectively, 7, 14, 21, 28, 35, and 42 days after implantation/rearing) (mean values \pm SE; $\mathrm{n}=3$ )

\begin{tabular}{|c|c|c|}
\hline \multirow[b]{2}{*}{ Parameters/days } & \multicolumn{2}{|l|}{ Group } \\
\hline & AT & $\mathrm{C}$ \\
\hline \multicolumn{3}{|l|}{ SL (cm) } \\
\hline d0 & $36.39( \pm 0.27)$ & $36.10( \pm 0.24)$ \\
\hline $\mathrm{d} 7$ & $36.63( \pm 0.22)$ & $36.41( \pm 0.29)$ \\
\hline $\mathrm{d} 14$ & $36.86( \pm 0.23)$ & $36.76( \pm 0.29)$ \\
\hline $\mathrm{d} 21$ & $36.99( \pm 0.24)$ & $36.82( \pm 0.25)$ \\
\hline $\mathrm{d} 28$ & $37.12( \pm 0.20)$ & $36.92( \pm 0.34)$ \\
\hline d35 & $37.33( \pm 0.18)$ & $37.27( \pm 0.36)$ \\
\hline $\mathrm{d} 42$ & $37.48( \pm 0.25)$ & $37.46( \pm 0.36)$ \\
\hline \multicolumn{3}{|l|}{ BW (g) } \\
\hline $\mathrm{d} 0$ & $605.92( \pm 11.13)$ & $615.42( \pm 17.43)$ \\
\hline $\mathrm{d} 7$ & $627.29( \pm 7.32)$ & $638.86( \pm 19.76)$ \\
\hline $\mathrm{d} 14$ & $635.82( \pm 3.53)$ & $645.34( \pm 19.47)$ \\
\hline $\mathrm{d} 21$ & $639.89( \pm 5.06)$ & $652.84( \pm 23.05)$ \\
\hline $\mathrm{d} 28$ & $644.86( \pm 4.31)$ & $660.32( \pm 24.60)$ \\
\hline d35 & $654.80( \pm 7.20)$ & $667.50( \pm 27.15)$ \\
\hline $\mathrm{d} 42$ & $661.08( \pm 6.27)$ & $675.78( \pm 26.27)$ \\
\hline \multicolumn{3}{|l|}{ F (-) } \\
\hline d0 & $1.26( \pm 0.01)$ & $1.31( \pm 0.01)$ \\
\hline $\mathrm{d} 7$ & $1.27( \pm 0.01)$ & $1.32( \pm 0.01)$ \\
\hline $\mathrm{d} 14$ & $1.27( \pm 0.03)$ & $1.30( \pm 0.01)$ \\
\hline $\mathrm{d} 21$ & $1.26( \pm 0.02)$ & $1.31( \pm 0.02)$ \\
\hline $\mathrm{d} 28$ & $1.26( \pm 0.03)$ & $1.31( \pm 0.02)$ \\
\hline d35 & $1.25( \pm 0.03)$ & $1.29( \pm 0.02)$ \\
\hline $\mathrm{d} 42$ & $1.25( \pm 0.03)$ & $1.29( \pm 0.02)$ \\
\hline \multicolumn{3}{|l|}{$\operatorname{DGR}\left(\mathrm{g} \mathrm{d}^{-1}\right)$} \\
\hline $\mathrm{d} 0-\mathrm{d} 7$ & $2.67( \pm 0.60)$ & $2.93( \pm 0.62)$ \\
\hline d8-d14 & $1.22( \pm 0.70)$ & $0.93( \pm 0.53)$ \\
\hline $\mathrm{d} 15-\mathrm{d} 21$ & $0.58( \pm 0.23)$ & $1.07( \pm 0.70)$ \\
\hline $\mathrm{d} 22-\mathrm{d} 28$ & $0.71( \pm 0.49)$ & $1.07( \pm 0.27)$ \\
\hline d29-d35 & $1.42( \pm 0.49)$ & $1.03( \pm 0.37)$ \\
\hline $\mathrm{d} 36-\mathrm{d} 42$ & $0.90( \pm 0.16)$ & $1.18( \pm 0.15)$ \\
\hline $\mathrm{d} 0-\mathrm{d} 42$ & $1.28( \pm 0.26)$ & $1.40( \pm 0.35)$ \\
\hline \multicolumn{3}{|l|}{$\operatorname{SGR}\left(\% \mathrm{~d}^{-1}\right)$} \\
\hline $\mathrm{d} 0-\mathrm{d} 7$ & $0.43( \pm 0.11)$ & $0.45( \pm 0.09)$ \\
\hline $\mathrm{d} 8-\mathrm{d} 14$ & $0.18( \pm 0.12)$ & $0.14( \pm 0.09)$ \\
\hline $\mathrm{d} 15-\mathrm{d} 21$ & $0.08( \pm 0.04)$ & $0.16( \pm 0.10)$ \\
\hline $\mathrm{d} 22-\mathrm{d} 28$ & $0.10( \pm 0.08)$ & $0.16( \pm 0.03)$ \\
\hline d29-d35 & $0.20( \pm 0.09)$ & $0.15( \pm 0.05)$ \\
\hline d36-d42 & $0.12( \pm 0.03)$ & $0.18( \pm 0.03)$ \\
\hline $\mathrm{d} 0-\mathrm{d} 42$ & $0.19( \pm 0.05)$ & $0.21( \pm 0.05)$ \\
\hline \multicolumn{3}{|l|}{ FCR (-) } \\
\hline $\mathrm{d} 0-\mathrm{d} 7$ & $1.45( \pm 0.30)$ & $1.34( \pm 0.25)$ \\
\hline d8-d14 & $5.88( \pm 2.27)$ & $2.85( \pm 0.03)$ \\
\hline $\mathrm{d} 15-\mathrm{d} 21$ & $10.37( \pm 4.42)$ & $3.64( \pm 1.09)$ \\
\hline
\end{tabular}


cont. Table 1

\begin{tabular}{lll}
\hline \hline & Group & \\
\cline { 2 - 3 } Parameters/days & AT & C \\
\hline \hline $\mathrm{d} 22-\mathrm{d} 28$ & $12.28( \pm 5.02)$ & $6.13( \pm 0.93)$ \\
$\mathrm{d} 29-\mathrm{d} 35$ & $3.61( \pm 0.96)$ & $3.52( \pm 0.51)$ \\
$\mathrm{d} 36-\mathrm{d} 42$ & $4.72( \pm 0.98)$ & $3.23( \pm 0.76)$ \\
$\mathrm{d} 0-\mathrm{d} 42$ & $3.33( \pm 0.66)$ & 0 \\
$\begin{array}{l}\text { Mortality (\%) } \\
\text { d0-d42 }\end{array}$ & 0 & - \\
AT retention (\%) & & \\
$\quad \mathrm{d} 0-\mathrm{d} 42$ & 83.33 & 100 \\
$\begin{array}{l}\text { PIT retention (\%) } \\
\text { d0-d42 }\end{array}$ & 100 & \\
\hline \hline
\end{tabular}

Details in Material and methods section. No significant statistical differences were confirmed among groups $(\mathrm{P}>0.05)$

compensatory growth can occur in tagged fish. A brief period of lowered growth rate is observed following tagging procedures after which short-term differences in growth between tagged and untagged fish equalize (Baras et al. 2000, Zakęś and Hopko 2013). In the present study the feed conversion ratio (FCR value) in both pikeperch groups (AT vs. C) was similar (in the period of $\mathrm{d} 0-\mathrm{d} 42$ approximately 3.3; Table 1); however, the FCR values must be considered to be high. This is most likely linked with the frequent, weekly manipulations of the fish that were required by the experimental design. Similarly high FCR values (3.3-3.7) are reported in experiments performed on juvenile European perch, Perca fluviatilis L. (BW approximately $75 \mathrm{~g}$; SL approximately $16 \mathrm{~cm}$ ) in which the fish were tagged with RT and reared under similar conditions (Rożyński et al. 2017b). While other studies performed on pikeperch (RT tagging; BW approximately $87 \mathrm{~g}$; SL approximately $20 \mathrm{~cm}$ ) report more advantageous FCR values (approximately 2.0) (Rożyński et al. 2017a), these also must be considered as too high, a value of 1.5 should not be exceeded in pikeperch (Zakęś et al. 2013). Although frequent fish manipulation is required in these types of studies, it is a significant stress factor that decreases the effectiveness of fish feeding. Importantly, the FCR values in the groups of fish tagged with RT or AT were similar to those calculated for the fish from the control group (Rożyński et al. 2017a, 2017b, this study). Similarly, Robertson et al. (2003) did not observe the surgical implantation of transmitters to impact the feeding effectiveness of Atlantic salmon, Salmo salar L. (BW approximately $40 \mathrm{~g}$, fork length (FL) approximately $15 \mathrm{~cm}$ ). In this study worse growth was noted in tagged fish, which could have been related to changes in their activity levels or to the occurrence of other metabolic costs in the fish that were tagged with telemetry transmitters (Cooke et al. 2011).

AT implantation did not have a significant impact on pikeperch hematological indexes (Table 2). In the group of pikeperch that were implanted with RT and in which the incisions were sutured with tissue adhesive, Rożyński et al. (2017a) also did not observe that this manipulation had an impact on blood parameters. However, in the same study when the incisions were sutured with silk sutures differences were noted in MCV and MCH values. This could indicate that the incision suturing method had an impact on fish health. In the present study, differences in the biochemical blood plasma indicators of pikeperch were only noted for glucose, the level of which in the AT group was approximately $16 \%$ lower than that in the control group ( $\mathrm{P} \leq 0.05$; Table 3$)$. Jepsen et al. (2001) report, inter alia, that the levels of lactates and glucose in the blood plasma of Chinook salmon smolts, Oncorhynchus tshawytscha (Walb.) 7 days following RT implantation stabilized 
Table 2

Hematological indexes of pikeperch (S. lucioperca) tagged with acoustic transmitters (group AT) and fish from the control group (group C) (mean values $\pm \mathrm{SE} ; \mathrm{n}=18)$

\begin{tabular}{llll}
\hline \hline & & Group & \\
\cline { 3 - 4 } Parameters & Unit & AT & C \\
\hline \hline WBC & $10^{3} \mu^{-1}$ & $65.46( \pm 3.60)$ & $60.94( \pm 5.13)$ \\
RBC & $10^{6} \mathrm{ll}^{-1}$ & $1.57( \pm 0.06)$ & $1.41( \pm 0.07)$ \\
HGB & $\mathrm{g} \mathrm{l}^{-1}$ & $25.65( \pm 1.13)$ & $22.94( \pm 1.09)$ \\
HCT & $\%$ & $29.06( \pm 1.12)$ & $27.61( \pm 1.18)$ \\
MCV & $\mathrm{fl}$ & $135.12( \pm 2.16)$ & $127.94( \pm 2.81)$ \\
MCH & $\mathrm{pg}$ & $26.76( \pm 0.68)$ & $26.41( \pm 0.84)$ \\
MCHC & $\mathrm{gl}^{-1}$ & $197.94( \pm 2.35)$ & $196.94( \pm 2.42)$ \\
PLT & $10^{3} \mu l^{-1}$ & $10.29( \pm 0.74)$ & $9.71( \pm 1.40)$ \\
\hline \hline
\end{tabular}

Details in Material and methods section. No significant statistical differences were confirmed among groups $(\mathrm{P}>0.05)$

and did not differ from those of the control group. In turn, Luo et al. (2014) report lower glucose levels in bighead carp, Hypophthalmichthys nobilis (Rich.) (BW approximately $900 \mathrm{~g}$, SL approximately $35 \mathrm{~cm}$ ) tagged with RT even after seven days. These authors also noted in this period differences in indexes such as ALT, AST, ALP, ALB, and GLOB; however, 14 days after tagging, these indexes (including that of glucose) assumed values similar to those observed in the bighead carp control group. In the present study differences in glucose levels were confirmed even 42 days after AT implantation, which could indicate the more persistent physiological impact of this procedure in pikeperch. The phenomenon of hypoglycemia could be linked with, inter alia, with the effects of chronic stress in fish (Maricchiolo et al. 2008). AT implantation and their presence in the body cavity could cause discomfort in the fish and be a source of stress. However, that AT implantation might not have had a significant impact on the values of the remaining biochemical indexes of pikeperch blood plasma is worthy of consideration (Table 3).

The tissue adhesive used to suture the incisions in pikeperch following AT implantation was shed over the course of two weeks (Fig. 1; Deters et al. 2010). A similar rate of adhesive shedding was observed in other studies in which pikeperch (BW approximately $87 \mathrm{~g}$; SL approximately $20 \mathrm{~cm}$ ) were implanted with RT (Rożyński et al. 2017a). In the present study, three weeks after AT implantation the surgical incisions were closed in all fish (rank 1 or 0; Miller et al. 2014). In subsequent weeks, the implantation incisions did not change (Fig. 1). The rate of incision healing was similar to that observed in earlier studies conducted on pikeperch, which demonstrated that suturing RT implantation incisions with tissue adhesive facilitates more rapid healing in comparison with suturing incisions with silk sutures (Rożyński et al. 2017a). It must be emphasized that in the studies cited, that regardless of the suturing method (tissue adhesive or silk sutures) no infection was noted. However, sometimes hyperemia and/or

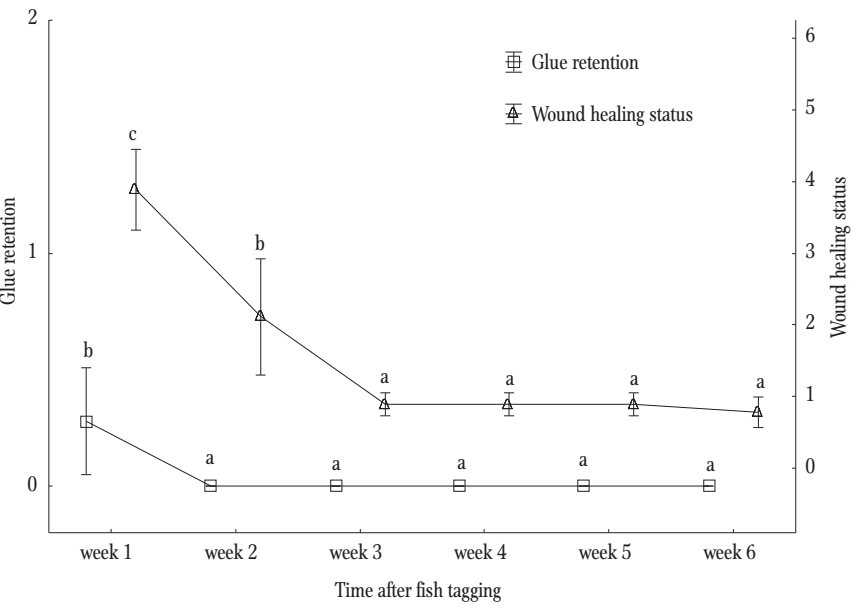

Figure 1. Tissue adhesive retention and incision healing in pikeperch $(S$. lucioperca) tagged with acoustic transmitters (mean values $\pm \mathrm{SE}$ ). Groups with different letter indexes differ significantly statistically (P $\leq$ 0.05) (Deters et al. 2010, Miller et al. 2014, Rożyński et al. 2017a). 
Table 3

Biochemical indexes of pikeperch (S. lucioperca) tagged with acoustic transmitters (group AT) and fish from the control group (group C) (mean values $\pm \mathrm{SE}, \mathrm{n}=18)$

\begin{tabular}{|c|c|c|c|}
\hline \multirow[b]{2}{*}{ Parameters } & \multirow[b]{2}{*}{ Unit } & \multicolumn{2}{|l|}{ Group } \\
\hline & & AT & $\mathrm{C}$ \\
\hline CREA & $\mathrm{mg} \mathrm{dl}^{-1}$ & $0.01( \pm 0.00)$ & $0.00( \pm 0.00)$ \\
\hline $\mathrm{TP}$ & $\mathrm{g} \mathrm{dl}^{-1}$ & $3.92( \pm 0.10)$ & $3.87( \pm 0.13)$ \\
\hline ALB & $\mathrm{g} \mathrm{dl}^{-1}$ & $1.73( \pm 0.05)$ & $1.77( \pm 0.06)$ \\
\hline GLOB & $\mathrm{g} \mathrm{dl}^{-1}$ & $2.19( \pm 0.08)$ & $2.10( \pm 0.09)$ \\
\hline GLU & $\mathrm{mg} \mathrm{dl}^{-1}$ & $77.89( \pm 3.02)^{\mathrm{a}}$ & $92.56( \pm 5.38)^{b}$ \\
\hline LACT & $\mathrm{mg} \mathrm{dl}^{-1}$ & $1.88( \pm 0.17)$ & $2.78( \pm 0.44)$ \\
\hline ALT & $\mathrm{U} \mathrm{l}^{-1}$ & $44.35( \pm 9.09)$ & $35.69( \pm 12.19)$ \\
\hline AST & $\mathrm{U} \mathrm{l}^{-1}$ & $31.18( \pm 5.48)$ & $31.71( \pm 9.26)$ \\
\hline ALP & $\mathrm{U} \mathrm{l}^{-1}$ & $65.18( \pm 3.04)$ & $61.69( \pm 4.75)$ \\
\hline $\mathrm{Ca}$ & $\mathrm{mg} \mathrm{dl}^{-1}$ & $10.29( \pm 0.15)$ & $10.40( \pm 0.18)$ \\
\hline $\mathrm{Cl}$ & $\mathrm{mmol} \mathrm{l}^{-1}$ & $150.34( \pm 6.08)$ & $157.41( \pm 8.37)$ \\
\hline $\mathrm{Mg}$ & $\mathrm{mg} \mathrm{dl}^{-1}$ & $2.80( \pm 0.04)$ & $2.83( \pm 0.08)$ \\
\hline $\mathrm{NH}_{3}$ & $\mu \mathrm{g} \mathrm{dl}^{-1}$ & $226.68( \pm 15.85)$ & $223.41( \pm 16.26)$ \\
\hline
\end{tabular}

Details in Material and methods section. Groups with different letter indexes differ significantly statistically $(\mathrm{P} \leq 0.05)$

inflammation are noted near the sutures of implantation incisions after a lengthy period (as much as 362 after transmitter implantation) (Caputo et al. 2009).

In the present study, AT retention was 83.3\% (d42). The fish shed ATs in weeks 1 and 2 following tagging, which is consistent with observations from studies of other fish species (Jepsen et al. 2002). Transmitters can be shed through the implantation incision, the skin, or the intestines (Jepsen et al. 2002). In the present study, the tags were shed from the fish body cavity through the implantation incision. It should be noted that in earlier studies when the incisions were sutured with tissue adhesive, RT retention in pikeperch was 100\% (Rożyński et al. 2017a). However, when perch (BW approximately $75 \mathrm{~g}$; SL approximately $16 \mathrm{~cm}$ ) incisions were sutured with tissue adhesive, RT retention was only 17.6\% (d42) (Rożyński et al. 2017b), but the transmitters used in the study were fitted with antennae that were directed outside of the body cavity, and these were attacked by other specimens. This resulted in the RTs moving within the body cavity, slower incision healing, and, in extreme cases, tag loss (Rożyński et al. 2017b). This phenomenon was not observed in the present study since the ATs were implanted entirely into the fish body cavity; however, some fish did shed their ATs ( $83.3 \%$ retention). This confirms that the value of the transmitter retention index depends on many factors, including fish species, specimen developmental stage, health, tag weight/size, body cavity length, and environmental conditions (Jepsen et al. 2002, Cooke et al. 2011).

In summation, surgically implanting AT (transmitter weight $6.4 \mathrm{~g})$ in pikeperch $(\mathrm{BW}>600 \mathrm{~g})$ did not adversely affect fish condition or health. Suturing implantation incisions with tissue adhesive was effective, and the rate of incision healing raised no concerns. The low glucose levels in the fish tagged with AT could raise some doubts; these could be, inter alia, the result of stress. This is a topic for further development, and this issue should be explored in greater detail in future studies.

Acknowledgments. This study was funded as part of statutory topic S-028 of the Stanisław Sakowicz Inland Fisheries Institute in Olsztyn. The study complied with ethical standards (permission from the Local Ethics Committee No. 24/2011, 30.03.2011).

Author contributions. Z.Z. designed the research; Z.Z. M.R., A.K., E.Z., and K.D.-Z. performed the research; Z.Z., M.R., A.K., E.Z., K.D-Z analyzed the data; Z.Z., M.R., A.K., K.D.-Z. wrote the paper. 


\section{References}

Baras E., Malbrouck C., Houbart M., Kestemont P., Mélard C. 2000 - The effect of PIT tags on growth and physiology of age-0 cultured Eurasian perch Perca fluviatilis of variable size - Aquaculture 185: 159-173.

Brinn R.P., Marcon J.L., Gomes D.M., Abreu L.C., Baldisseroto B. 2012 - Stress responses of the endemic freshwater cururu stingray (Potamotrygon cf. histrix) during transportation in the Amazon region of the Rio Negro - Comp. Biochem. Physiol. A 162: 139-145.

Caputo M., O’Connor C.M., Hasler C.T., Hanson K.C., Cooke S.J. 2009 - Long-term effects of surgically implanted telemetry tags on the nutritional physiology and condition of wild freshwater fish - Dis. Aquat. Org. 84: 35-41.

Cooke S.J., Woodley C.M., Eppard M.B., Brown R.S., Nielsen J.L. 2011 - Advancing the surgical implantation of electronic tags in fish: a gap analysis and research agenda based on a review of trends in intracoelomic tagging effects studies - Rev. Fish Biol. Fish. 21: 127-151.

Deters K.A., Brown R.S., Carter K.M., Boyd J.W., Eppard M.B., Seaburg A.G. 2010 - Performance assessment of suture type, water temperature, and surgeon skill in juvenile Chinook salmon surgically implanted with acoustic transmitters - Trans. Am. Fish. Soc. 139: 888-899.

FAO 2012 - Cultured Aquatic Species Information Programme. Sander lucioperca. Cultured Aquatic Species Information Programme - In: FAO Fisheries and Aquaculture Department [online]. Roma, Italy (text by Z. Zakęś), http://www.fao.org/fishery/culturedspecies/Sander_lucioperca/en (accessed 03 February 2018).

Hockersmith E.E., Beeman J.W. 2012 - A history of telemetry in fishery research - In: Telemetry techniques: a user guide for fisheries research (Eds.) N.S. Adams, J.W. Beeman, J.H. Eiler, American Fisheries Society, Bethesda, Maryland, USA: 7-19.

Horký P., Slavík O., Bartoš L. 2008 - A telemetry study on the diurnal distribution and activity of adult pikeperch, Sander lucioperca (L.), in a riverine environment Hydrobiologia 614: 151-157.

Hussey N.E., Kessel S.T., Aarestrup K., Cooke S.J., Cowley P.D., Fisk A.T., Harcourt R.G., Holland K.N., Iverson S.J., Kocik J.F., Mills Flemming J.E., Whoriskey F.G. 2015 Aquatic animal telemetry: a panoramic window into the underwater world - Science 348: 1255642.

Jepsen N. 2003 - Long-term retention of surgically implanted radio transmitters in pikeperch - J. Fish Biol. 63: 260-262.

Jepsen N., Davis L.E., Schreck C.B., Siddens B. 2001 - The physiological response of chinook salmon smolts to two methods of radio-tagging - Trans. Am. Fish. Soc. 130: 495-500.

Jepsen N., Koed A., Økland F. 1999 - The movements of pikeperch in shallow reservoir - J. Fish Biol. 54: 1083-1093.

Jepsen N., Koed A., Thorstad E.B., Baras E. 2002 - Surgical implantation of telemetry transmitters in fish: how much have we learned? - Hydrobiologia 483: 239-248.
Keskinen T., Pääkkönen J.P.J., Lilja J., Marjomäki T.J., Karjalainen J. 2005 - Homing behaviour of pikeperch (Sander lucioperca) following experimental transplantation - Boreal Environ. Res. 10: 119-124.

Kristan J., Stara A., Polgesek M., Drasovean A., Kolarova J., Priborsky J., Blecha M., Svacina P., Policar T., Velisek J. 2014 - Efficacy of different anaesthetics for pikeperch (Sander lucioperca L.) in relation to water temperature Neuroendocrinol. Lett. 35: 81-85.

Luo H., Duan X., Liu S., Chen D. 2014 - Effects of surgically implanted dummy ultrasonic transmitters on physiological response of bighead carp Hypophthalmichthys nobilis - Fish Physiol. Biochem. 40:1521-1532.

Maricchiolo G., Caruso G., Genovese L. 2008 - Haematological and immunological response in juvenile sea bass (Dicentrarchus labrax L.) after short-term acute stress Open Fish Sci. J. 1: 28-35.

Miller E.A., Froehlich H.E., Cocherell D.E., Thomas M.J., Cech J.J. Jr., Klimley A.P., Fangue N.A. 2014 - Effects of acoustic tagging on juvenile green sturgeon incision healing, swimming performance, and growth - Environ. Biol. Fish. 97: 647-658.

Poulet N., Lek S., Argillier C. 2005 - Pikeperch habitat use within a canal network in spring - J. Fish Biol. 67: 1460-1474.

Robertson M.J., Scruton D.A., Brown J.A. 2003 - Effects of surgically implanted transmitters on swimming performance, food consumption and growth of wild Atlantic salmon parr - J. Fish Biol. 62: 673-678.

Rożyński M., Kapusta A., Demska-Zakęś K., Hopko M., Sikora A., Zakęś Z. 2017a - The effects of surgically implanted dummy tags on the survival, growth performance, and physiology of pikeperch (Sander lucioperca) - Fish Physiol. Biochem. 34: 999-1010.

Rożyński M., Kapusta A., Demska-Zakęś K., Ziomek E., Szczerbowski A., Stawecki K., Zakęś Z. 2017b - Impact of two telemetry transmitter implantation incision suturing methods on the physiological state and condition of perch (Perca fluviatilis) - Arch. Pol. Fish. 25: 89-101.

Thorstad E.B., Rikardsen A.H., Alp A., Økland F. 2013 - The use of electronic tags in fish research - an overview of fish telemetry methods - Turk. J. Fish. Aquat. Sci. 13: 881-896.

Val A.L., Affonso E.G., Dealmeidaval V.M.F. 1992 - Adaptive features of amazon fishes - blood characteristics of curimata (Prochilodus cf nigricans, osteichthyes) Physiol. Zool. 65: 832-843.

Wagner G.N., Cooke S.J., Brown R.S., Deters K.A. 2011 Surgical implantation techniques for electronic tags in fish - Rev. Fish Biol. Fish. 21: 71-81.

Zakęś Z., Hopko M. 2013 - Tagging juvenile pikeperch (Sander lucioperca (L.)) in the cheek with Passive Integrated Transponders (PIT) - impact on rearing indexes and tag retention - Arch. Pol. Fish. 21: 243-248.

Zakęś Z., Hopko M., Kowalska A., Partyka K., Stawecki K. 2013 - Impact of feeding pikeperch Sander lucioperca (L.) feeds of different particle size on the results of the initial on-growing phase in recirculation systems - Arch. Pol. Fish. 21: 3-9. 